\title{
Pendekatan Starter Eksperimen Berbantuan Lembar Kerja Siswa untuk Meningkatkan Hasil Belajar IPA
}

\author{
*N K Ayu Risnawati1 ${ }^{1}$ N K Yuni Antari ${ }^{2}$ \\ ${ }^{1}$ Program Studi PEP, Program Pascasarjana Universitas Pendidikan Ganesha, Indonesia
}

${ }^{2}$ Sekolah Dasar No 4 Sulangai, Indonesia

\section{A R T I C L E I N F O}

Article history:

Received 15 August 2019

Received in revised form

20 September 2019

Accepted 10 October 2019

Available online 27

November 2019

Kata Kunci:

Pendekatan Starter

Eksperimen, Lembar Kerja

Siswa, hasil belajar IPA.

Keywords:

Experimental Starter

Approach, Student

Worksheet, Result science

learning outcomes..

\begin{abstract}
A B S T R A K
Penelitian ini bertujuan untuk mengetahui pengaruh Pendekatan Starter Eksperimen berbantuan Lembar Kerja Siswa terhadap peningkatan hasil belajar IPA. Jenis penelitian ini adalah penelitian eksperimen dengan rancangan post-test only control group design. Populasi dalam penelitian ini adalah seluruh siswa kelas IV Sekolah Dasar Gugus III Kecamatan Buleleng indonesia Sampel penelitian ini sebanyak 66 orang yang diperoleh dengan teknik random sampling. Data hasil belajar IPA dikumpulkan dengan menggunakan tes pilihan ganda dan dianalisis menggunakan teknik statistik uji-t dengan taraf signifikansi 0,05 . Hasil penelitian menunjukkan rata-rata nilai post-test kelompok dengan pendekatan Starter Eksperimen berbantuan Lembar Kerja Siswa lebih tinggi dari kelompok dengan pembelajaran konvensional. Berdasarkan hasil analisis data didapatkan nilai thit > dari tab sehingga dapat disimpulkan bahwa terdapat pengaruh yang signifikan Pendekatan Starter Eksperimen berbantuan Lembar Kerja Siswa terhadap peningkatan hasil belajar IPA.
\end{abstract}

\begin{abstract}
A B S T R A C T
This study aims to determine the effect of the experimental starter approach assisted by student worksheets on improving science learning outcomes. This type of research is experimental research with post-test only control group design. The population in this study were all student in class IV cluster III elementary school in Buleleng district. The samples of this study were 66 people obtained by random sampling technique. Science learning outcomes were collected using multiple choice tests and analyzed by t-test statistical techniques with significance level of 0,05 . The result showed that the average post test score of the experimental starter approach group was higher than the group with conventional models. Can be concluded that there is an influence of the experimental starter approach assisted by student worksheets on improving science learning outcomes.
\end{abstract}

\section{Pendahuluan}

Jenjang pendidikan dasar merupakan pondasi untuk melangkah ke jenjang pendidikan yang lebih tinggi. Jadi, penanaman konsep yang tepat sangat penting dilakukan pada jenjang pendidikan dasar. Perkembangan kognitif siswa pada jenjang pendidikan dasar masih berada pada tahap operasional konkret. Pada tahap ini, anak telah dapat membuat pemikiran tentang situasi atau hal konkret secara logis. Siswa Sekolah Dasar (SD) memandang sesuatu hal secara holistik atau menyeluruh sehingga dalam pembelajaran guru harus mampu menghadirkan "dunia nyata" ke dalam kelas. Belajar adalah tingkah laku yang diubah melalui latihan atau pengalaman (Ismail, 2016: 33). Untuk itu, pembelajaran yang dilaksanakan haruslah terpusat pada siswa bukan bersifat "Teacher-centered" sehingga guru hanya berperan sebagai motivator, fasilitator, serta memberikan bimbingan kepada siswa-siswanya.

Pada jenjang pendidikan dasar, terdapat lima mata pelajaran yang wajib dibelajarkan pada siswa. Mata pelajaran tersebut antara lain Matematika, Bahasa Indonesia, IPS, PKn, dan IPA. Sumber materi pada mata pelajaran tersebut umumnya dekat dengan kehidupan sehari-hari siswa. IPA merupakan salah satu 
mata pelajaran yang memanfaatkan lingkungan alam sekitar dan gejala-gejala yang terjadi di alam sebagai sumber belajar. IPA adalah pengetahuan yang sistematis dan tersusun secara teratur, berlaku umum, dan berupa kumpulan data hasil observasi dan eksperimen (Depdiknas, 2006:4). IPA merupakan mata pelajaran di SD yang dimaksudkan agar siswa mempunyai pengetahuan, gagasan, dan konsep yang terorganisir tentang alam sekitar yang, diperoleh dari pengalaman melalui serangkaian proses ilmiah antara lain, penyelidikan, penyusunan, dan penyajian gagasan (Balukh, Jusak Ariyanto, Hery Kresnadi, 2015). Itu sebabnya, dalam pembelajaran IPA seorang guru dituntut untuk mengajak siswa terlibat langsung dalam memanfaatkan alam sekitar sebagai sumber belajar. Alam sekitar merupakan sumber belajar yang paling otentik dan tidak akan habis digunakan (Widiartha, 2018). Pada mata pelajaran IPA, pemahaman konsep sangat penting karena setiap konsep yang dipelajari saling berkaitan. Pemilihan dan penggunaan pendekatan yang kurang tepat dapat menghambat pembentukan konsep dalam diri siswa. Siswa yang belajar tanpa berbuat langsung, akan menghasilkan konsep yang bersifat hapalan. Sedangkan siswa yang belajar dengan berbuat langsung, akan menghasilkan pemahaman konsep yang lebih baik dan lama diingat. Nana Sudjana (2008:3) mendefinisikan hasil belajar siswa pada hakikatnya adalah perubahan tingkah laku sebagai hasil belajar dalam pengertian yang lebih luas mencakup bidang kognitif, afektif, dan psikomotorik. Penelitian dari Sri Winarti Durandt, Irwan Said, dan Ratman (2013) memaparkan bahwa hasil belajar IPA adalah tercapainya target pembelajaran IPA yang sesuai dengan fungsinya dimana fungsi pembelajaran IPA di Sekolah Dasar (SD) mencakup komponen-komponen produk ilmiah, metode ilmiah dan sikap ilmiah.

Pembelajaran di sekolah dasar khususnya pada mata pelajaran IPA masih belum optimal. Hal ini berdampak pada rendahnya kualitas produk pengajaran IPA di Sekolah Dasar. Rendahnya kualitas yang dihasilkan pada produk pengajaran IPA dapat dilihat dari nilai ulangan umum siswa. Dari enam Sekolah Dasar di Gugus III Kecamatan Buleleng diperoleh nilai rata-rata ulangan umum siswa kelas IV untuk mata pelajaran IPA seperti tertera pada Tabel 1.

Tabel 1. Hasil Belajar IPA siswa kelas IV di gugus III Kecamatan Buleleng.

\begin{tabular}{clcc}
\hline No & Nama Sekolah Dasar & Nilai rata-rata ulangan semester ganjil & KKM IPA \\
\hline 1 & SD 1 Jinengdalem & 65 & 75 \\
2 & SD 2 Jinengdalem & 76 & 70 \\
3 & SD 3 Jinengdalem & 71 & 68 \\
4 & SD 5 Jinengdalem & 79 & 70 \\
5 & SD No. 1 Poh Bergong & 74 & 74 \\
6 & SD No. 2 Poh Bergong & 70 & 77 \\
\hline
\end{tabular}

(Sumber: Arsip nilai ulangan umum IPA kelas IV Sekolah Dasar di Gugus III Kecamatan Buleleng semester ganjil )

Pada Tabel 1, diketahui nilai rata-rata ulangan semester untuk mata pelajaran IPA belum optimal karena masih ada siswa yang nilainya kurang dari KKM yang ditetapkan. Salah satu penyebab belum optimalnya hasil belajar IPA adalah kurangnya pemahaman siswa terhadap konsep-konsep IPA. Proses pembelajaran IPA di Sekolah Dasar masih sering menggunakan pembelajaran konvensional. Guru menjadi pusat informasi dan murid menerima informasi dari guru. Interaksi antara guru dengan siswa kurang optimal, sebab siswa hanya terlibat pasif dalam pembelajaran. Karena aktivitas siswa kurang, maka siswa menjadi bosan dan kurang memperhatikan penjelasan guru. Untuk itu, diperlukan suatu inovasi dalam pembelajaran agar siswa dapat terlibat aktif, membangkitkan minat siswa dalam belajar, serta membangun kemandirian dan tanggung jawab siswa dalam penyelesaikan tugas.

Penerapan Pendekatan Starter Eksperimen dapat digunakan sebagai solusi dalam upaya meningkatkan hasil belajar IPA. Pendekatan Starter Eksperimen yang diadopsi dari kata "Starter Eksperiment Approach" dikembangkan pertama kali oleh Schoenher J pada tahun 1996. (Artha Saputra, Sujana, 2018) menyebutkan "Pendekatan Starter Eksperimen memiliki kelebihan antara lain: (1) dapat menarik minat siswa untuk mempelajari IPA, (2) meningkatkan aktivitas dan kreativitas siswa, (3) membiasakan siswa berpikir dan bertindak ilmiah, (4) memperlihatkan adanya keterkaitan IPA dengan lingkungan". Penelitian yang dilakukan oleh (Mei Indiarini \& Bayu, 2019) menunjukkan bahwa rata rata skor hasil belajar dari kelompok eksperimen yang di berikan perlakuan pembelajaran Starter Experiment Approach (SEA) adalah sebesar 22,96. Sedangkan rata-rata skor hasil belajar IPA pada siswa yang tidak menggunakan perlakuan Starter Eksperiment Approach (SEA) adalah sebesar 16,57.

Pendekatan Starter Eksperimen berbantuan Lembar Kerja Siswa sangat mendukung dalam pembelajaran IPA. Lembar kerja siswa (student work sheet) adalah lembaran-lembaran yang berisi petunjuk, interupsi, tugas/kegiatan yang harus dikerjakan oleh siswa. Lembar Kerja Siswa berisi informasi 
dan perintah/instruksi dari guru kepada siswa untuk mengerjakan suatu kegiatan belajar dalam bentuk kerja, praktek, atau dalam bentuk penerapan hasil belajar untuk mencapai suatu tujuan (Safriandono \& Charis, 2014). Dengan menggunakan Lembar Kerja Siswa, siswa dapat mengeksplorasi ide, saling bekerja sama dalam kelompok, mengembangkan kreativitasnya, serta membangun kemandirian dan tanggung jawab atas tugas yang diberikan. Petunjuk dan informasi yang terdapat dalam Lembar Kerja Siswa disusun agar siswa dapat mengaitkan hasil temuan dengan konsep yang sedang dipelajari. Jadi, Lembar Kerja Siswa tidak hanya berfungsi dalam memudahkan siswa untuk melakukan percobaan juga menuntun siswa untuk menyusun dan mengaitkan hasil temuan dalam percobaan dengan materi yang dipelajari.

Pendekatan Starter Eksperimen berbantuan Lembar Kerja Siswa merupakan pendekatan yang memberikan kesempatan kepada siswa untuk terlibat aktif dalam pembelajaran IPA. Dengan terlibat secara langsung, siswa akan lebih termotivasi untuk mempelajari materi-materi IPA. Berdasarkan petunjuk dan informasi pada Lembar Kerja Siswa, konstruksi pengetahuan dengan cara mengintegrasikan ide yang dimiliki siswa dapat berlangsung optimal. Pendekatan ini menggunakan metode-metode ilmiah sehingga memungkinkan siswa untuk menemukan serangkaian fakta dari percobaan yang dilakukan. Dengan memanfaatkan phenomena di lingkungan sekitar, pembelajaran yang dilakukan menjadi bermakna.

Bertolak dari uraian di atas, dilakukan penelitian mengenai "Pendekatan Starter Eksperimen Berbantuan Lembar Kerja Siswa untuk meningkatkan Hasil Belajar IPA Siswa Kelas IV Sekolah Dasar di Gugus III Kecamatan Buleleng”.

\section{Metode}

Rancangan dalam penelitian ini adalah eksperimen semu karena tidak semua variabel dikontrol secara ketat. Desain penelitian yang digunakan dalam penelitian ini adalah post-test only control group design (Sugiyono, 2007). Populasi dalam penelitian ini adalah adalah seluruh siswa kelas IV Sekolah Dasar di Gugus III Kecamatan Buleleng. Dari populasi tersebut diambil dua kelas untuk kelas eksperimen dan kelas kontrol. Teknik pengambilan sampel penelitian menggunakan teknik random sampling dan terpilih kelas IV SD N 1 Jinengdalem sebagai kelas eksperimen dengan jumlah 31 siswa dan kelas IV SD N 1 Poh Bergong sebagai kelas kontrol dengan jumlah 35 siswa. Dengan demikian jumlah sampel dalam penelitian ini adalah 66 orang siswa.

Teknik pengumpulan data yang digunakan adalah tes hasil belajar IPA dengan skala nominal 0 dan 1. Analisis data yang digunakan adalah teknik analisis t-test dengan prasyarat uji normalitas sebaran data dan uji homogenitas varian sampel.

\section{Hasil dan Pembahasan}

Untuk menguji hipotesis dalam penelitian maka data yang dikumpulkan dalam penelitian ini adalah hasil belajar IPA kelompok eksperimen maupun kelompok kontrol. Kemudian data tersebut dianalisis dengan menggunakan ststistik deskriptif untuk mengetahui mean, modus, median dan standar deviasi. Ringkasan statistik deskritif disajikan pada tabel berikut:

Tabel 2. Rekapitulasi Nilai -Nilai Statistik Data Hasil Belajar IPA untuk Kelompok Eksperimen dan Kelompok Kontrol

\begin{tabular}{lcc}
\hline Data Statistik & Kelompok Eksperimen & Kelompok Kontrol \\
\hline Mean & 18,05 & 12,91 \\
Median & 18,70 & 11,95 \\
Modus & 19,83 & 10,81 \\
Standar Deviasi & 5,53 & 4,36 \\
\hline
\end{tabular}

Uji hipotesis dalam penelitian ini dengan uji-t. Kriteria pengujian adalah tolak $\mathrm{H}_{0}$ jika $t_{\text {hit }}>\mathrm{t}_{\text {tab }}$. Data hasil post-test siswa kelompok eksperimen dan kelompok kontrol dianalisis dengan uji-t sehingga diperoleh hasil perhitungan seperti Tabel 3.

Tabel 3. Rangkuman Hasil Uji-t

\begin{tabular}{ccccccc}
\hline Sampel & $\mathrm{N}$ & $\mathrm{dk}$ & $\bar{X}$ & $\mathrm{SD}$ & $\mathrm{t}_{\text {hitung }}$ & $\mathrm{t}_{\text {tabel }} 5 \%$ \\
\hline Kelompok Eksperimen & 31 & 64 & 18,05 & 5,53 & 34,27 & 2,00 \\
Kelompok Kontrol & 35 & & 12,91 & 4,36 & & \\
\hline
\end{tabular}


Dari Tabel di atas diketahui thitung $>t_{\text {tabel }}(34,27>2,00)$. Berdasarkan kriteria pengujian $\mathrm{H}_{0}$ ditolak dan $\mathrm{H}_{1}$ diterima, ini berarti hasil belajar IPA siswa yang belajar menggunakan Pendekatan Starter Eksperimen berbantuan Lembar Kerja Siswa berbeda dengan hasil belajar siswa yang menggunakan pembelajaran konvensional pada siswa kelas IV Sekolah Dasar di Gugus III Kecamatan Buleleng. Dilihat dari nilai rerata hitung, ternyata kelompok siswa yang dibelajarkan dengan Pendekatan Starter Eksperimen berbantuan Lembar Kerja Siswa lebih tinggi daripada kelompok siswa yang dibelajarkan dengan pembelajaran konvensional $\left(\bar{X}_{\text {eksperimen }}=18,05>\bar{X}_{\text {kontrol }}=12,91\right)$. Ini berarti, pembelajaran dengan Pendekatan Starter Eksperimen berbantuan Lembar Kerja Siswa berpengaruh terhadap hasil belajar IPA siswa kelas IV Sekolah Dasar di Gugus III Kecamatan Buleleng.

Pembelajaran dengan Pendekatan Starter Eksperimen difasilitasi Lembar Kerja Siswa memberikan kesempatan kepada siswa untuk mengeksplorasi segala ide dan kemampuan siswa untuk menemukan sendiri pengetahuannya. Dalam Lembar Kerja Siswa, pertama-tama siswa mengamati percobaan yang didemonstrasikan oleh guru. Selama guru mendemonstrasikan percobaan, siswa diberikan kesempatan untuk mengamati dan mencatat hasil pengamatan. Dari data hasil pengamatan, siswa diminta mengemukakan dugaan sementara atas permasalahan yang diberikan oleh guru. Dugaan sementara ini diuji secara berkelompok dengan tuntunan petunjuk pada Lembar Kerja Siswa.

Pendekatan Starter Eksperimen dan pembelajaran konvensional yang diterapkan dalam penelitian ini menunjukkan pengaruh yang berbeda terhadap hasil belajar IPA. Siswa kelompok eksperimen yang dibelajarkan dengan Pendekatan Starter Eksperimen berbantuan Lembar Kerja Siswa memiliki hasil belajar yang lebih baik dibandingkan dengan siswa kelompok kontrol yang dibelajarkan dengan pembelajaran konvensional. Diketahui rata-rata hasil belajar siswa kelompok eksperimen yang dibelajarkan dengan Pendekatan Starter Eksperimen berbantuan Lembar Kerja Siswa adalah 18,05. Sedangkan rata-rata hasil belajar siswa kelompok kontrol yang dibelajarkan dengan pembelajaran konvensional adalah 12,91. Hasil ini menunjukkan bahwa adanya perbedaan rata-rata hasil belajar antara siswa kelompok eksperimen yang dibelajarkan dengan Pendekatan Starter Eksperimen lebih tinggi dibandingkan dengan rata-rata hasil belajar siswa kelompok kontrol yang dibelajarkan dengan pembelajaran konvensional. Hal ini selaras dengan hasil penelitian yang dilakukan oleh (Agustini et al., 2019) yang menyatakan bahwa terdapat perbedaan hasil belajar IPA yang diakibatkan oleh model pembelajaran dan diperoleh juga hasil bahwa rerata hasil belajar IPA dari kelompok yang dikenai model Pendekatan Starter Eksperimen lebih tinggi dari rerata hasil belajar IPA kelompok yang dikenai model pembelajaran konvensional.

Perbedaan ini terjadi karena keseluruhan kegiatan model pembelajaran dengan pendekatan Starter Eksperimen menunjukkan bahwa aktivitas pembelajaran didominasi oleh siswa baik secara individual maupun kelompok. Kondisi ini memberikan kesempatan seluas luasnya kepada siswa dalam mengembangkan kemampuan untuk berpikir. Keterlibatan siswa secara langsung dalam pembelajaran IPA akan memberi kesempatan bagi siswa untuk melatih keterampilan proses sainnya (Nyeneng et al., 2015)

Berdasarkan hasil analisis data dengan menggunakan uji-t diperoleh $t_{\text {hitung }}=34,27$, dengan $d k=64$ pada taraf signifikansi $5 \%$ diketahui $t_{\text {tabel }}=2,00$. Hasil perhitungan tersebut menunjukkan $t_{\text {hitung }}>t_{\text {tabel }}$ yaitu 34,27 > 2,00. Ini berarti, thitung lebih besar dibandingkan dengan tabel sehingga terdapat perbedaan nilai rata-rata hasil belajar IPA pada siswa kelompok eksperimen yang dibelajarkan dengan Pendekatan Starter Eksperimen berbantuan Lembar Kerja Siswa dengan siswa kelompok kontrol yang dibelajarkan dengan pembelajaran konvensional. Jadi, hasil belajar IPA siswa kelompok eksperimen yang dibelajarkan dengan Pendekatan Starter Eksperimen berbantuan Lembar Kerja Siswa lebih tinggi dibandingkan dengan siswa kelompok kontrol yang dibelajarkan dengan pembelajaran konvensional. Hal ini didukung dengan hasil penelitian yang dilakukan oleh (Dibia \& Adiasih, 2017) tentang Pendekatan Starter Eksperimen. Hasil penelitian menunjukkan bahwa penerapan Pendekatan Starter Eksperimen dapat meningkatkan hasil belajar ranah kognitif mata pelajaran IPA siswa kelas IV Sekolah Dasar No. 2 Banjar Tegal Kecamatan Buleleng. Hal ini dapat terlihat dari nilai rata-rata siswa yaitu 57,35. sebelum diberi tindakan yang tergolong rendah meningkat menjadi 66,76. pada siklus I, Kemudian meningkat menjadi 80 pada siklus II yang tergolong tinggi.

Pencapaian hasil belajar IPA siswa yang dibelajarkan dengan Pendekatan Starter Eksperimen berbantuan Lembar Kerja Siswa lebih tinggi dibandingkan dengan siswa yang dibelajarkan dengan pembelajaran konvensional, disebabkan oleh perlakuan langkah-langkah pembelajaran dan proses penyampaian materi selama pembelajaran berlangsung. Pembelajaran dengan Pendekatan Starter Eksperimen memberikan kesempatan kepada siswa untuk berperan aktif dalam pembelajaran. Siswa menemukan serangkaian fakta melalui kegiatan eksperimen yang dilakukan secara berkelompok dengan tuntunan Lembar Kerja Siswa. Menurut (Bestari, D. Yulianti, 2014) langkah-langkah pembelajaran dengan Pendekatan Starter Eksperimen meliputi yaitu percobaan awal (starter experiment), pengamatan 
(observation), rumusan masalah, dugaan sementara, percobaan pengujian, penyusunan konsep, mencatat pelajaran, penerapan konsep, dan evaluasi dilakukan oleh siswa dengan difasilitasi oleh guru. Pengalaman yang diperoleh siswa selama pembelajaran akan mengalami asimilasi dan akomodasi dengan pengetahuan awal yang telah dimilikinya. Pengetahuan baru yang lebih lengkap terbentuk dan akan bertahan lama dalam ingatan siswa, sebab siswa sendirilah yang mengkonstruksi pengetahuan tersebut.

Pendekatan Starter Eksperimen adalah terjemahan dari "Starter Experiment Approach", merupakan pendekatan komprehensif untuk pengajaran IPA yang mencakup berbagai strategi pembelajaran yang biasanya diterapkan secara terpisah dan berorientasi pada keterampilan proses (Suastra, 2006). Pendekatan Starter Eksperimen mempunyai ciri khusus yaitu mengetengahkan alam lingkungan sebagai penyulut (starter), selanjutnya pembelajaran dilakukan dengan mempraktekkan prinsip-prinsip metode ilmiah meliputi pengamatan, dugaan sementara, desain percobaan, eksperimen, dan laporan hasil penelitian (Sri Lestari, 2016). Terdapat delapan (8) langkah dalam pembelajaran IPA dengan pendekatan starter eksperimen seperti percobaan awal, pengamatan, rumusan masalah, dugaan sementara, percobaan pengujian, penyusunan konsep, penerapan konsep, dan evaluasi (Suastra, 2009). Langkah-langkah pembelajaran dengan Pendekatan Starter Eksperimen sangat mendukung siswa untuk aktif dalam proses pembelajaran.

Langkah pertama, percobaan awal yang didemonstrasikan oleh guru. Demonstrasi yang dilakukan oleh guru bertujuan untuk menggugah rasa ingin tahu siswa dan minat siswa untuk belajar. Selain itu, pada tahap ini guru memberikan kesempatan kepada siswa untuk membantu guru mendemonstrasikan percobaan awal. Selama demonstrasi, siswa diminta untuk mengamati dan mencatat hasil pengamatan. Jadi, dari awal pembelajaran siswa sudah diarahkan untuk aktif dalam pembelajaran. Langkah kedua yaitu pengamatan terhadap percobaan yang didemonstrasikan guru. Pengamatan ini dilakukan secara perseorangan. Melalui pengamatan, siswa mengumpulkan informasi/data-data hasil percobaan yang didemonstrasikan oleh guru. Selama pengamatan, siswa memperhatikan dengan tekun kemudian mencatat hasilnya pada Lembar Kerja Siswa. Hasil pengamatan didiskusikan bersama kelompok kemudian disampaikan kepada guru. Langkah ketiga, yaitu perumusan masalah. Setelah siswa selesai mengamati dan mencatat hasil pengamatan, guru mengajukan pertanyaan yang bersumber dari hasil pengamatan. Secara berkelompok siswa mendiskusikan jawaban dari pertnyaan yang diajukan guru. Langkah keempat, yaitu dugaan sementara. Setiap siswa diberikan kesempatan untuk mengemukakan jawaban atas pertanyaan yang diajukan guru. Jawaban yang dikemukakan siswa kemudian dikumpulkan. Jawaban yang paling mengena dengan konsep yang akan dipelajari dipilih sebagai dugaan sementara yang akan dibuktikan melalui percobaan. Langkah kelima, pengujian (verifikasi). Siswa secara berkelompok menyusun desain percobaan secara terbimbing dengan tuntunan Lembar Kerja Siswa, melakukan percobaan pengujian dan mencatat temuan yang diperoleh. Selama percobaan, guru membimbing dan menuntun siswa apabila menemui kesulitan dalam melakukan percobaan. Langkah keenam, perumusan konsep. Usai percobaan siswa mendiskusikan hasil temuannya kemudian mempresentasikan di depan kelas. Guru memberikan penegasan terhadap hasil temuan siswa agar sesuai dengan konsep yang dipelajari. Jadi, temuan siswa yang kurang tepat diberikan penegasan sehingga konsep yang diperoleh menjadi tepat. Langkah ketujuh, yaitu penerapan konsep. Pada tahap ini, siswa mengaitkan temuan yang diperoleh dengan materi perubahan lingkungan fisik daratan yang dipelajari. Berdasarkan temuan tersebut, siswa dapat menyebutkan penyebab bencana alam serta cara pencegahannya. Langkah kedelapan, yaitu evaluasi. Untuk mengetahui tingkat pemahaman siswa terhadap materi yang dipelajari maka diadakan evalusi. Dari evaluasi, guru dapat mengetahui materi yang sudah dikuasai dengan baik dan yang belum oleh siswa sehingga guru dapat mengambil suatu tindakan.

Guru dalam pembelajaran dengan Pendekatan Starter Eksperimen berperan sebagai fasilitator dan mediator yang memberikan kesempatan kepada siswa untuk melakukan aktivitas belajar, mengemukakan ide maupun pendapat. Siswa sendirilah yang aktif mengkonstruksi pengalaman belajar yang diterimanya menjadi pengetahuan sekaligus memanfaatkan pengetahuan tersebut dalam pembelajaran. Berdasarkan hasil pengujian data, Rata-rata skor post-test yang diperoleh siswa kelompok eksperimen lebih tinggi dibandingkan dengan rata-rata yang diperoleh siswa kelompok kontrol. Dengan demikian, pembelajaran dengan menggunakan Pendekatan Starter Eksperimen berbantuan Lembar Kerja Siswa berpengaruh terhadap peningkatan hasil belajar IPA siswa kelas IV di Gugus III Kecamatan Buleleng.

\section{Simpulan dan Saran}

Dari hasil penelitian dan pembahasan dapat disimpulkan bahwa terdapat pengaruh yang signifikan Pendekatan Starter Eksperimen berbantuan Lembar Kerja Siswa terhadap peningkatan hasil belajar IPA. Pencapaian hasil belajar IPA siswa yang dibelajarkan dengan Pendekatan Starter Eksperimen berbantuan Lembar Kerja Siswa lebih tinggi dibandingkan dengan siswa yang dibelajarkan dengan pembelajaran 
konvensional, disebabkan oleh perlakuan langkah-langkah pembelajaran dan proses penyampaian materi selama pembelajaran berlangsung. Pembelajaran dengan Pendekatan Starter Eksperimen memberikan kesempatan kepada siswa untuk berperan aktif dalam pembelajaran.

Terkait dengan hasil penelitian, beberapa saran yang diajukan seperti berikut: (1) Kepada guru pengajar IPA agar lebih sering melibatkan siswa dalam kegiatan pembelajaran melalui Pendekatan Starter Eksperimen agar siswa dapat membentuk pengetahuannya melalui pengalaman yang dialami secara langsung; (2) mendorong penelitian lanjutan agar meneliti permasalahan ini dalam lingkup yang lebih luas sehingga diperoleh sumbangan ilmu yang lebih baik dan sesuai dengan perkembangan jaman.

\section{Daftar Rujukan}

Agustini, A., Suastra, W., Suarni, K., Studi, P., Dasar, P., \& Pascasarjana, P. (2019). Pengaruh Model Pembelajaran Starter Experiment Approach Terhadap Keterampilan Proses Dan Hasil Belajar Ipa Siswa Kelas Vi Sd. 3(2), 62-73.

Artha Saputra, Sujana, M. (2018). Korelasi Antara Kecerdasan Interpersonal Dengan Hasil Belajar Ips Siswa Kelas V Di Sd Gugus Iv Abiansemal Tahun Pelajaran2017/2018. Indonesian Journal Of Educational Research and Review, 1(1), 11-20. https://doi.org/10.23887/ijerr.v1i1.14618

Balukh, Jusak Ariyanto, Hery Kresnadi, M. A. (2015). Peningkatan Hasil Belajar Siswa Dalam Pembelajaran IPA Menggunakan Metode Kerja Kelompok Di Sekolah Dasar. Jurnal Pendidikan Dan Pembelajaran Untan, 4(12).

Bestari , D. Yulianti, P. D. (2014). Pembelajaran Fisika Menggunakan Sea Berbantuan Games Untuk Mengembangkan Karakter Siswa SMP. Unnes Physics Education Journal, 3(3), 77-83.

Dibia, I. K., \& Adiasih, M. M. (2017). Penerapan Pendekatan Starter Eksperimen (Pse) Untuk Meningkatkan Hasil Belajar Mata Pelajaran Ipa. International Journal of Elementary Education, 1(1), 72. https://doi.org/10.23887/ijee.v1i1.11442

Depdiknas. 2006. Peraturan Menteri Pendidikan Nasional No. 22 Tahun 2006 Tentang Standar Isi Untuk Satuan Pendidikan Dasar dan Menengah. Jakarta: Departemen Pendidikan Nasional.

Ismail. 2016. Edukasi: Diagnosis Kesulitan Belajar Siswa Dalam Pembelajaran Aktif di Sekolah. Aceh: jurnal UIN Ar-Raniry Banda Aceh, 2 (1): 33

Mei Indiarini, N. M. R., \& Bayu, G. W. (2019). Pengaruh Starter Experiment Approach (Sea) Terhadap Hasil Belajar Ipa. Mimbar Ilmu, 24(1), 124-133. https://doi.org/10.23887/mi.v24i1.17469

Nyeneng, I., Lasmawan, M., \& Dantes, P. (2015). Pengaruh Model Pendekatan Starter Eksperimen (Pse) Terhadap Keterampilan Proses Sains Dan Hasil Belajar Sains Siswa Sd Gugus Viii Kecamatan Abang. Jurnal Pendidikan Dasar Ganesha, 5(1), 124522.

Safriandono, A. N., \& Charis, M. (2014). Rancang Bangun E-Lembar Kerja Siswa sebagai Media Pembelajaran yang Praktis, Fleksibel dan Edukatif Berbasis Web. Jurnal Teknik-UNISFAT, 10(1), 2535.

Sri Lestari. (2016). Meningkatkan Kemampuan Pemecahan Masalah Fisika Kelas XI Iis 1 Sma Muhammadiyah 2 Yogyakarta Melalui Pembelajaran Sea (Starter Experiment Approach). Jurnal Ilmiah Guru Caraka Olah Pikir Edukatif, 19(2).

Suastra, I. W. (2006). Belajar dan Pembelajaran Sains. Undiksha Press.

Suastra, I. W. (2009). Pembelajaran Sains Terkini: Mendekatkan Siswa dengan Lingkungan Alamiah dan Sosial Budayanya. Undiksha Press.

Sudjana, Nana. 2008. Penilaian Hasil Proses Belajar Mengajar. Bandung: Remaja Rosdakarya 
Sugiyono. (2007). Statistika untuk Penelitian (Revisi Terbaru). Alfabeta.

Sri Winarti Durant, I. S. "Meningkatkan Hasail Belajar IPA Khususnya Materi Energi dan Perubahannya Melalui Pembelajaran Quantum Teaching di Kelas V SDN Inpres Matamaling”. Jurnal Kreatif Tadulako Online , 2014 http://jurnal.untad.ac.id/jurnal/index.php/JKTO/article/download/2942/20 22

Widiartha, K. D. R. (2018). Pengaruh Model Pembelajaran Visualization Auditory Kinestetic Berbantuan Mutimedia Interaktif Terhadap Kompetensi Pengetahuan IPA. Jurnal Penelitian Dan Pengembangan Pendidikan, 2(2), 145. https://doi.org/10.23887/jppp.v2i2.15396 